Tamara Sass

Państwowa Wyższa Szkoła Zawodowa w Głogowie

\title{
Wolność jako czynnik stymulujący i destruktywny w działalności pedagoga sztuki
}

Wybierając temat związany z wolnością, zrobiłam ukłon w stronę tego, co mnie samą we własnej pracy grafika fascynuje i niepokoi. A ponieważ to, co nas interesuje szczególnie i osobiście, naturalnie przenosimy na kolejne sfery życiowej działalności, zaczęłam stawiać pytania dotyczące twórczej aktywności dziecka podobne do tych, które można zadać w odniesieniu do dojrzałej pracy artystycznej. Dla logicznego porządku i metodycznej przyzwoitości rozpocznę od definicji wolności. Nie chcąc wchodzić w rozważania natury filozoficznej, do których nie mam stosownego przygotowania, zaproponuję prosto brzmiącą słownikową definicję: „Wolność - niezależność, swoboda,

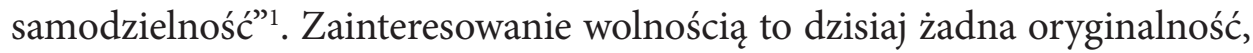
dla większości ma ona status specjalny. Fanatyczne wręcz uwielbienie, jakim potrafimy ją niekiedy obdarzać, potrafi doprowadzić do niepokoju czy nawet agresji, w sytuacji gdy ktoś lub coś przesuwa nam jej granice. Wolność ma wiele twarzy i wszystkie przynajmniej pobieżnie rozpoznajemy. Mamy więc np. wolność słowa, wyznania, wolność orientacji seksualnej. W obecnych czasach, gdy wartość obiektywną i powszechną praktycznie zanegowano, wolność akceptujemy jako wartość wszyscy i sankcjonujemy konieczność jej powszechności. Przestrzeń wyboru to imperatyw wpisany w sytuację współczesnego człowieka. Kiedy jednak myślimy o doskonałej wolności, niekoniecznie przychodzi nam do głowy samowola skutkująca chaosem. Raczej z całą odpowiedzialnością akceptujemy paradoks polegający na tym, że wolność jest ograniczona koniecznością zewnętrzną, którą próbujemy rozumieć i akceptować, oraz wewnętrzną, do której próbujemy dorosnąć.

Wolność, której doświadczamy w świecie, może być zaobserwowana w mikroskali, w sztuce współczesnej. Brak spójnego katalogu wartości wiodących wywołuje stan multiplikacji celów i dążeń. Możliwość swobodnego

\footnotetext{
${ }^{1}$ S. Skorupka, H. Auderska, Z. Łempicka (red.), Mały słownik języka polskiego, Warszawa 1969, s. 906.
} 
dostępu do wiedzy pokoleń, gwarantowana dzięki powszechności tekstów drukowanych i zasobności faktograficznej przestrzeni Internetu, daje nam niewyobrażalnie szerokie możliwości. Panujący indywidualizm pozwala na pełny eklektyzm w posługiwaniu się dziedzinami, stylami i technikami. Artyści mogą również zaskakiwać bez konieczności udowadniana fachowości rzemieślniczej, wystarczy pomysł, najlepiej szokujący, przekraczający granice, zatrzymujący nas w egzystencjalnym biegu. $Z$ definicji Morrisa Steina ${ }^{2}$ wynika, że aby coś było twórcze, powinno być nowe i wartościowe. Ponieważ z rozpoznaniem wartości, $\mathrm{z}$ racji ich indywidualnego odczuwania, możemy mieć kłopot, pozostaje naturalna skłonność do koncentracji na aspekcie nowości. Ta skłonność otrzymuje szczególne wsparcie mediów, które żywią się ciągłym głodem sensacji i nowości. Media mają również niezwykły potencjał promowania i deprecjonowania sztuki, nie zawsze zgodnie z jakimś przemyślanym kryterium. Czasem do wyniesienia sztuki wystarczy, że będzie krzyczała głośno i nietypowo. W takim świecie i w kontekście takiej sztuki funkcjonujemy.

Z tej konkluzji rodzi się pytanie: Jak zatem przygotować dzieci, młodzież do wszechogarniającej multiwartościowości i dać konieczne wsparcie do rozpoznania kodów współczesnej kultury? Myślę, że chcąc znaleźć odpowiedź na postawione powyżej pytanie, jako pedagodzy sztuki powinniśmy jej szukać w kontekście tego, co w świecie istotne, w kontekście wolności. W związku z tym można by zaproponować koncentrację wokół takich celów pedagogiki sztuki, jak: kształcenie umiejętności dysponowania wolnością własną, kształtowanie szacunku i zrozumienia dla wolności innych, rozumienie, jak tworzą ludzie wolni, oraz dlaczego sztuka współczesna ma tyle twarzy i nie wszystkie są czytelne.

Specyficzne ujęcie wolności proponuje Maria Montessori, pisząc: „Wolność i dyscyplina to dwie strony tego samego medalu"3. Tam proponowana koincydencja z porządkiem (zasada wolności i porządku) i dyscypliną nakierowuje nas na wolność typu „od”. Wolność od ograniczeń, od niemożności, od chaosu. Do wolności tego typu dochodzimy chociażby przez powtarzalność czynności, co po odpowiednim czasie i stosownej dawce zaangażowania daje efekt w postaci swobody i profesjonalizmu. I pomimo dbałości o granice wolności nie niepokoi nas ten pozorny paradoks, że wolność można kształtować poprzez dyscyplinowanie. Nie niepo-

\footnotetext{
${ }^{2}$ E. Nęcka, Psychologia twórczości, Gdańsk 2002, s. 17.

${ }^{3}$ M. Miksza, Zrozumieć Montessori, Kraków 2009, s. 73.
} 
koi, ponieważ mamy świadomość, że zbyt szerokie spektrum wyboru może doprowadzić do sytuacji, którą poetycko da się zilustrować za pomocą cytatu z filozofa Sørena Kierkegaarda: „lęk jest dla wolności zawrotem głowy, [...] wolność zerka w dół ku swej możliwości, a wtedy chwyta skończoność i trzyma się jej"4.

Mając zbyt szerokie spektrum wyboru, można doświadczyć bezradności, poczucia, że nie wiadomo nawet, od czego zacząć. Nieadekwatna do sytuacji, zbyt duża, dawka wolności może przynieść niepokój zamiast radości i w ramach stosownej autorefleksji skłonić do obawy przed odpowiedzialnością, która, jak wiemy, rośnie wprost proporcjonalnie do zakresu przestrzeni wolności. Zgrabne odwołanie do kontekstu odpowiedzialności odnajdziemy w słowach Pawła, w Pierwszym Liście do Koryntian: „Wszystko mi wolno, ale nie wszystko jest pożyteczne"5. Tekst nowotestamentowy brzmi prosto, pragmatyczne i zdroworozsądkowo. Stanowi właściwie pewne ujęcie szukania równowagi pomiędzy koniecznością a wolnością. Równowaga ta dla pedagoga sztuki jest istotna, ponieważ szukamy doskonałej kompozycji, która łączyłaby swobodę twórczą, planowane efekty edukacyjne, dbałość o bezpieczny i harmonijny rozwój osobowości dziecka lub nastolatka.

Jak wspomniałam, w społeczeństwie, które najbardziej ceni wolność, trzeba nauczyć młodych ludzi, jak się z nią obchodzić. Nie tylko o samą wolność chodzi, istotne staje się również rozpoznanie i zaakceptowanie tego, w jakim otoczeniu się przebywa. Nieodłącznymi towarzyszami wolności, którymi w kontekście pracy pedagogicznej chciałabym się przyjrzeć, są lęk, odpowiedzialność i dyscyplina. Obserwując zależność, jaka zachodzi pomiędzy zakresem przestrzeni wolności a poziomem realizacji efektów edukacyjnych, i chcąc dojść do konkluzji, które miałyby aspekt wspierający moją pracę pedagogiczną, doszłam do przekonania, że powinnam odwołać się do konkretnych działań uczniów realizowanych w ramach zajęć plastyki lub edukacji artystycznej.

Pierwsze zadanie było z założenia realizowane w standardzie równowagi pomiędzy wolnością daną uczniom a narzuconą im koniecznością. Skierowane zostało do dwóch grup wiekowych. Pierwszą stanowili gimnazjaliści, którzy zostawieni w przestrzeni miejskiej, tworzyli cykle plenerowych szkiców z natury (il. 1a, b).

\footnotetext{
${ }^{4}$ B. Alex, Søren Kierkegaard - życie prawdziwe, Warszawa 1998, s. 77.

${ }_{5}^{5}$ Pismo Święte Starego i Nowego Testamentu, Brytyjskie i Zagraniczne Towarzystwo Biblijne, Warszawa 1967, s. 177.
} 
Szkice miały być wykonywane ołówkiem na formacie A4. W gestii uczniów pozostawiono: znaleźć stosowny motyw architektoniczny, ustalić kadr eksponowany w pracy i dać sobie tyle czasu na wytworzenie rysunku, ile każdemu potrzeba. Druga grupa to klasa VI szkoły podstawowej, dla której zadanie polegało na stworzeniu parafrazy malarskiej techniką olejną na płótnie, odnoszącej się do impresjonizmu. Tematem prac był wschód słońca.
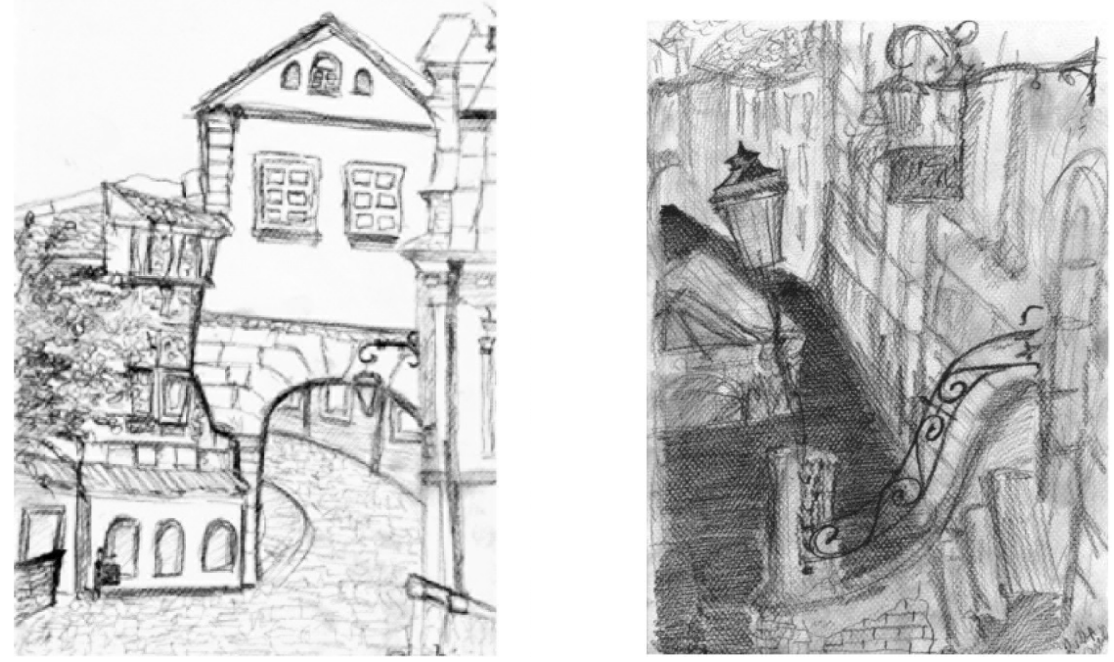

Il. 1a, b. Plenerowy szkic z natury, kl. I gimnazjum

Element wspólny działań w obu grupach stanowiła zakładana wcześniej podobna liczba i specyfika narzuconych ograniczeń. Dla uczniów pracujących w plenerze dane były: temat, miejsce, technika i format, a dla tych w pracowni - temat, format, technika i czas realizacji. Dla obu grup wolność koncentrowała się wokół wyboru motywu i kadru, oczywiście jedni poszukiwali go w otoczeniu, drudzy w pamięci i wyobraźni. Ponieważ cel polegał na wytworzeniu pracy plastycznej adekwatnej do narzuconego tematu, odpowiedzialność uczniów dotyczyła sposobów realizacji. W obu grupach do pracy przystępowano bez obaw. Wśród gimnazjalistów temat plenerowy wspierany obserwacją nie rodził wstępnych pytań. Możliwość szkicowania poza czujnym okiem nauczyciela dawała szansę wielokrotnych prób i przeprowadzania autoewaluacji bez ograniczania się czasem. Również zadanie malarskie realizowane przez młodszych uczniów nie płoszyło twórczych instynktów. Działo się tak, ponieważ temat przywoływał zjawisko ogólnie 
znane (wschód słońca) a zastosowanie techniki pointylizmu pozwalało na zgrabne ukrycie błędów rysunkowych. Obie grupy działały sprawnie i każdy zdołał stworzyć pracę adekwatną do tematu. Podsumowując, należałoby stwierdzić, że niezależnie od różnic wynikających z tematu, techniki, wieku uczniów - równowaga tego, co dane do tego, co zadane doprowadzała do sprawnej realizacji zadania.

Czy podobna sprawność realizacyjna utrzyma się, jeśli będziemy tę równowagę zaburzać? Czy więcej „oddechu” danego uczniom wpłynie na efektywność ich pracy? Szukając odpowiedzi na te pytania, zaproponowałam trzem klasom na różnym poziomach edukacji szkolnej, gimnazjalistom, uczniom z kl. VI i kl. IV, pracę na podobny temat, związany z poszukiwaniem własnej tożsamości i tę samą technikę - fotografię aranżowaną. Ta fotograficzna praca koncepcyjna miała określony temat dla każdej grupy. Dla

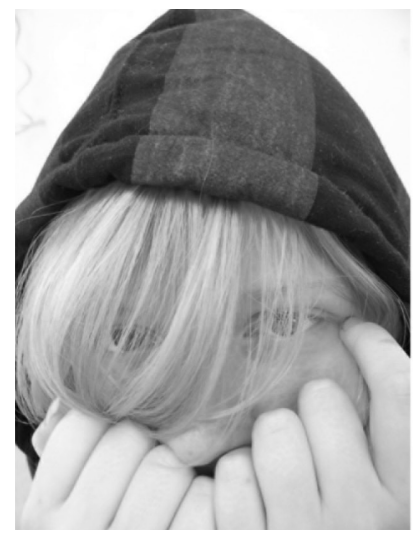

Il. 2a, b, c. Cykl ćwiczeń skoncentrowanych na poszukiwaniu własnej tożsamości, realizowanych jako fotografie aranżowane

gimnazjalistów - „Ja” (il. 2a), dla szóstoklasistów „On” (il. 2b), dla uczniów klasy czwartej - „Ja jako On” (il. 2c).

Nie chciałam ingerować w swobodę interpretacyjną, więc zaproponowałam zróżnicowanie stopnia trudności poprzez, jak je nazwałam, „elementy dookreślające”. Te dla najstarszych należały do obszaru abstrakcji - światło ruch, mimika, dla szóstoklasistów „elementem dookreślającym” był jak najbardziej materialny, choć jednocześnie pozbawiony konkretności znaczeniowej papier toaletowy. Należało jej poszukać, aby mógł spełnić swoją funkcję i stać się albo całunem, albo szalem, albo przepaską. Najbardziej konkretnie przedstawiały się te elementy u najmłodszych, ponieważ 
potrzebowali oni określonych atrybutów, aby opisać wymyśloną przez siebie postać. Przynosili więc kapelusze, płaszcze, naczynia, aby stworzyć tożsamość rycerza, kucharki, sklepikarza. W obu zadaniach liczył się w równym stopniu i wytwór, i proces. Można było zaobserwować, czy twórcza ekspresja podlegała lękom i bezradności, czy eksponowała się w zabawie pełnej spontanicznie multiplikowanych pomysłów. Wykonane przez uczniów zdjęcia są dowodem nieskrępowanej przestrzeni interpretacji, nieszablonowości i dobrej zabawy.

Oczywiście praca koncepcyjna oparta na wyobraźni, gdzie obszar wolności jest duży, musi być dostosowana do wieku, dlatego w działaniach na bazie pełnej abstrakcji, zabawy znakiem, symbolem najlepiej sprawdzają się dojrzalsi uczestnicy. Projekt „Mendel ludzki” (il. 3), skierowany do studentów, opierał się na formie owalu-jaja, którego wnętrze należało wypełnić fotograficznie rejestrowaną fakturą oddającą zjawiska różnych kontekstów i zależności, jak przykładowa triada - młodość, dojrzałość, starość. To było twórcze wyzwanie, w którym faktura, forma i kolorystyka musiały zostać oderwane od rzeczywistego kontekstu, aby mogło powstać coś nowego. Zrealizowane tryptyki były nie tylko czytelne w przekazie, ale również interesujące $\mathrm{w}$ formie.
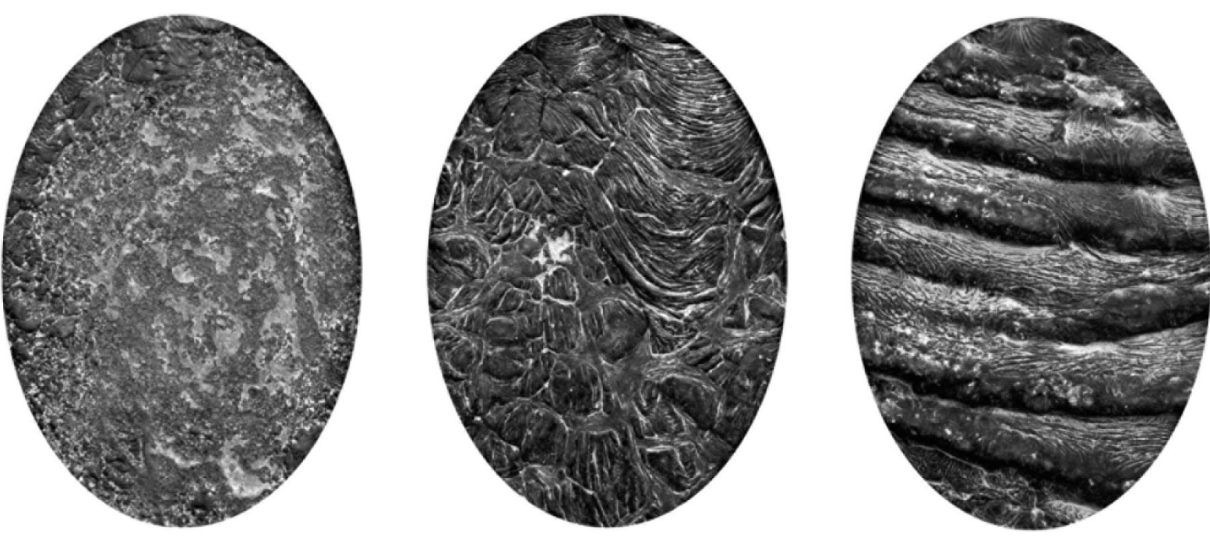

Il. 3. „Mendel ludzki”, fotograficzne zadanie koncepcyjne, realizowane przez studentów I roku studiów licencjackich

Kolejnym wyzwaniem edukacyjnym okazało się przygotowanie zadania, w którym pozostawiłam uczniom wolny wybór w każdej sprawie poza ostateczną kategorią wytworzenia. Miał powstać film animowany, trwający minimum $10 \mathrm{~s}$. Wszystko inne należało wymyślić samemu: temat, scena- 
riusz, technikę, to czy praca będzie realizowana samemu czy w grupie, jaki program komputerowy będzie układał sekwencje zdjęć w zaplanowanym ciągu narracyjnym. Oczywiście zadanie ma sens tylko wtedy, kiedy celem nadrzędnym jest obserwacja zachowania uczniów w odniesieniu do proponowanego wyzwania, a nie tylko konieczność wytworzenia czegokolwiek, w tym przypadku filmu. Szeroki wachlarz wyboru doprowadził do przewidywalnej sytuacji wstępnego twórczego lęku, który u części osób doprowadził do chaosu i zniechęcenia, $u$ innych ulegał stopniowemu oswojeniu i nie przeszkodził w ustaleniu strategii działań i powstaniu animacji. Powstało niewiele prac, ale te filmy, które zrealizowano, były bardzo osobiste i interesujące.

Proponując kolejnej grupie podobne zadanie, zmieniłam zakres wolnego wyboru i zaproponowałam wykonanie filmu na podstawie przeczytanej książki. Tym razem wszyscy zrealizowali animacje, a brak konieczności myślenia o scenariuszu pozwolił na ciekawe rozwiązania techniczne - bohaterowie wylepiani byli z plasteliny, budowani z klocków, usypywani z cukru. Chcąc podsumować działania nad filmem w obu grupach, należy stwierdzić, że praca z dużą przestrzenią wolności poza tym, że wymaga więcej czasu, ma również charakter dość elitarny. Tylko niektóre jednostki dają radę pokonać wstępną bezradność i zrealizować zadaną pracę.

Ponieważ kształcenie w ramach pedagogiki sztuki odbywa się zarówno poprzez działania zbiorowe, jak i indywidualne, przyjrzałam się działaniom zespołowym w kontekście wolnego wyboru danego uczniom. Realizacje, które teraz opiszę, mają zasadniczo tylko jedną cechę wspólną. Są przeznaczone do realizacji przez grupę. Pierwsza grupa to dzieci z klas 0-3, które po wpuszczeniu do pracowni dostały pudło pasteli olejnych, karton 150 x $100 \mathrm{~cm}$ i propozycję tematu. Miały stworzyć kosmos lub podwodny świat (il. 4). Mogły chodzić po kartonie i rysować, jak chcą. Spontaniczna zabawa, w czasie której dzieci naturalnie ustalały zasady bezkonfliktowych ruchów, weryfikowały swoje rysunki poprzez porównanie, doprowadzała do samonapędzającej się ochoty, aby pracować lepiej i dokładniej.

Zupełnie innym działaniem było przygotowanie zadania typu performance, wystawionego w łódzkiej Manufakturze (il. 5).

Młodzież gimnazjalna pracowała na przygotowanym przeze mnie scenariuszu, opracowując sposób poruszania się postaci, dynamikę poszczególnych scen, rekwizyty i scenografię. Performance stanowił próbę wizualnej refleksji wobec wyboru: być czy mieć. Kontrast pojęć był definiowany 


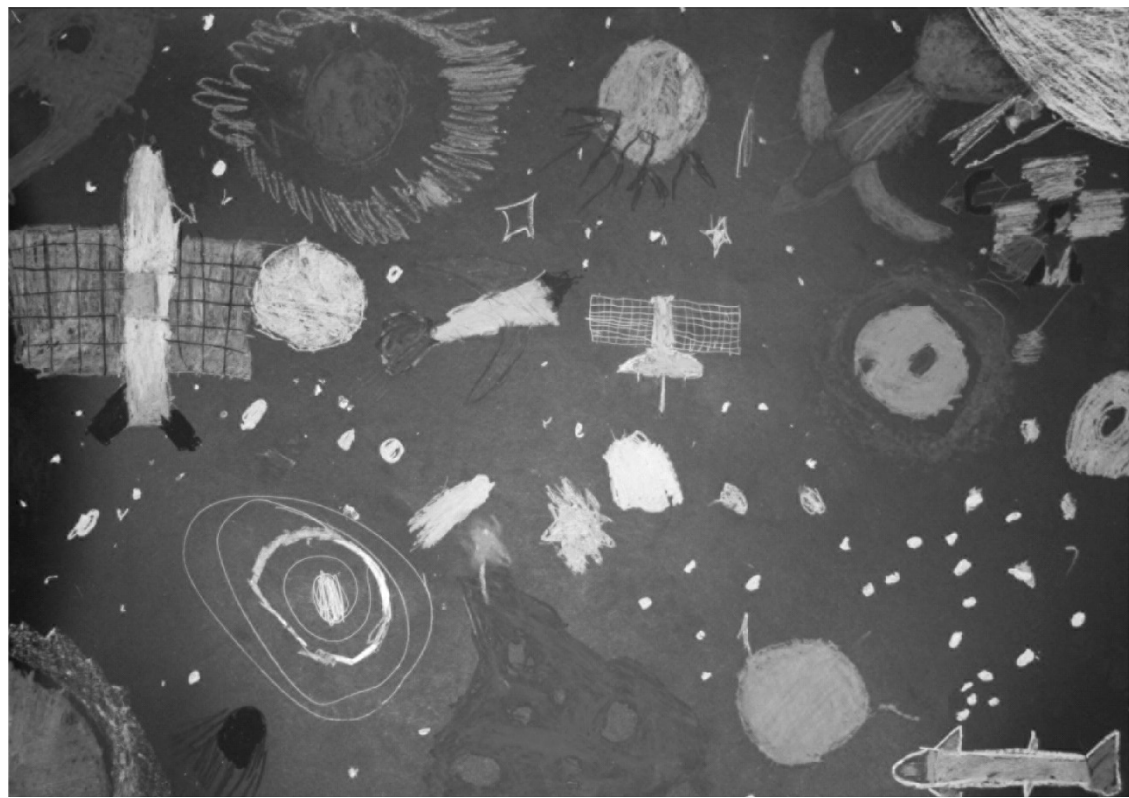

Il. 4. Kosmos, praca zbiorowa pastelami olejnymi, kl. I-III SP

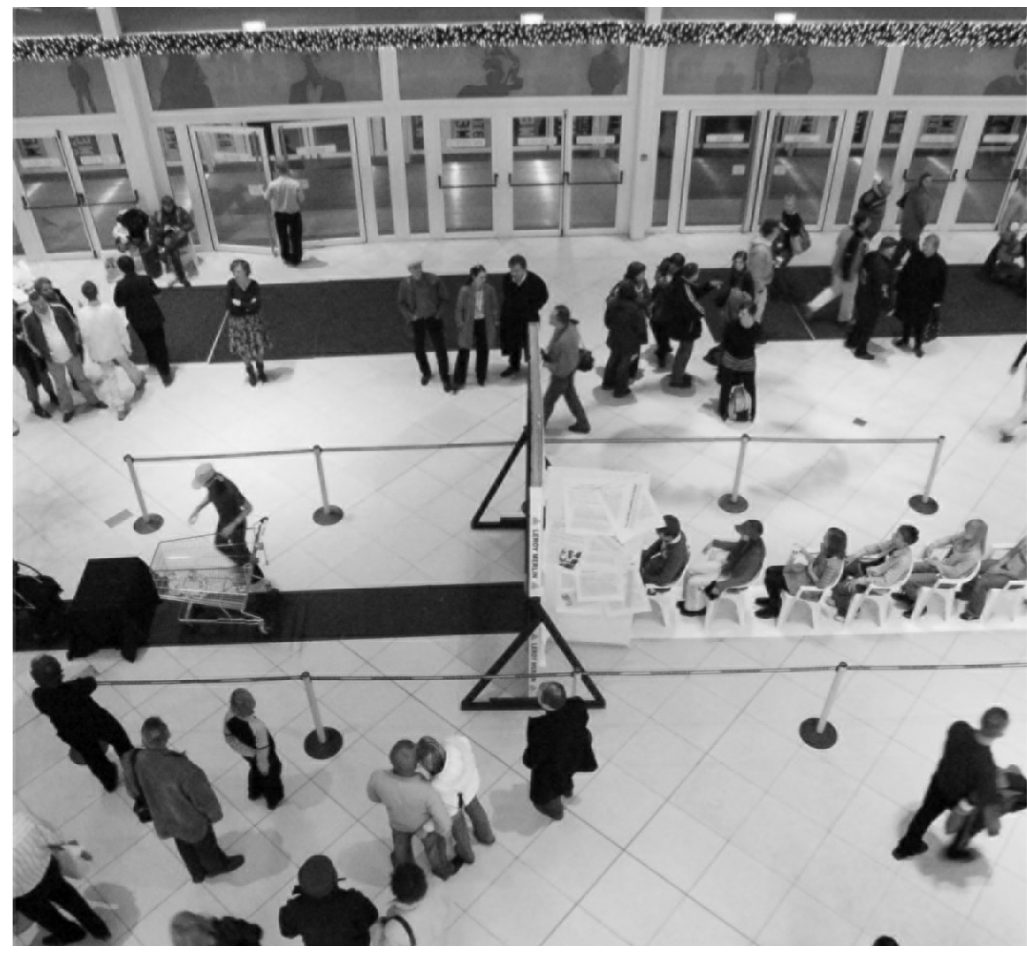

Il. 5. Performance w łódzkiej Manufakturze, Mieć czy być, kl. I-III gimnazjum 
kontrastem bieli i czerni, które z założenia dominowały odbiór estetyczny całości. Przedstawienie wymagało silnej wzajemnej korelacji i wysokiej precyzji ruchów. Miało charakter ronda, kilkakrotnie odtwarzanego po to, aby przypadkowy przechodzień robiący zakupy mógł obejrzeć całość. Duża grupa widzów skupiająca się wokół, swobodne komentarze z tłumu oraz przedstawiciele radia i telewizji stały się oczywistymi nośnikami pewnego stresu u gimnazjalistów. Chcąc przedstawić powyższe realizacje i porównać oba działania, zacznę od aspektu odpowiedzialności, który im towarzyszył. W zbiorowym rysowaniu pomimo działania grupowego każde dziecko koncentrowało się na wytworzeniu własnego obrazu. Brało odpowiedzialność tylko za siebie, a nawet i ten zakres był łagodzony faktem, że pojedynczy rysunek ginął wśród innych przedstawień. W performance młodzież brała odpowiedzialność nie tylko za swoje działanie, ale również za działanie pozostałych uczestników. Gra jednej osoby zazębiała się przecież z grą innych, a każdy indywidualny błąd przekładał się na jakość całości.

Poza wspomnianą tu odpowiedzialnością, z twórczą wolnością związany jest też aspekt lęku. W grupie dzieci poziom lęku okazał się bardzo niski. Rysowały bez zahamowań, ponieważ proponowany temat był dla nich prosty, podobnie jak i technika, a stosowny poziom unifikacji pracy indywidualnej na rzecz wspólnego wytworu eliminował konieczność eksponowania tylko własnego rysunku. Młodzież od momentu przygotowywania scenografii poprzez samą realizację przedstawienia, aż do momentu zakończenia i kontaktu z mediami, narażona była na ciągły proces weryfikacji ze strony obserwatorów. Poziom lęku był więc bardzo wysoki i wieloaspektowy. Łączył się z wątpliwościami typu: Czy przedstawienie uda się poprawnie odegrać? Czy przesłanie zostało wystarczająco jasno zobrazowane? Czy grając w przedstawieniu, nie narażę się na śmieszność, szczególnie w oczach rówieśników?

Pozostając jeszcze przez chwilę przy omawianiu działań zbiorowych, chciałabym napisać parę słów na temat dyscypliny w obu grupach. Oczywiście przygotowanie performance wymagało od młodzieży wielokrotnych prób, które doprowadzały do coraz swobodniejszej gry. Konieczności silnego zdyscyplinowania doświadczała ona również podczas żmudnych przygotowań scenografii i precyzyjnego dopracowywania logistyki, związanej z dniem samej prezentacji. Dzieci natomiast, rysując, dyscyplinowały się tylko w aspekcie ujarzmiania agresji wobec przechodzącego pod ręką kolegi. Musiały co najwyżej uważać, aby wzajemnie nie przeszkadzać so- 
bie w pracy. Omówione powyżej przykłady działań grupowych różniły się zatem między sobą zasadniczo innym poziomem odpowiedzialności, lęku i dyscypliny. Pomimo tych różnic u uczestników obu grup obserwowano wysoki poziom satysfakcji, w przypadku dzieci doświadczanej przede wszystkim w trakcie samego procesu, w przypadku młodzieży - uświadamianej i przeżywanej post factum.

Można również, koncentrując się na wolności, podjąć rozważania dotyczące ciekawej zależności pomiędzy wolnością dziecka a odpowiedzialnością pedagoga. Jak szerokie powinno być spektrum wolności, aby wychowanek poradził sobie z potencjalnością wyborów i oczekiwany efekt edukacyjny został osiągnięty, a pasja twórcza mogła znaleźć wyraz w śmiałej ekspresji, która doprowadzi do satysfakcji i radości ucznia? Wprowadzenie nadmiaru dyscypliny przy realizacji grupowego rysunku zaburzyłoby spontaniczny proces twórczy małego dziecka. Natomiast rezygnacja z prób przed przedstawieniem naraziłaby młodzież na zagubienie, poczucie bezradności i zawstydzenie.

Możliwość przewidywania formalnych i emocjonalnych konsekwencji proponowanych zadań dałaby nam, pedagogom twórczości, wysoką skuteczność realizacji zakładanych celów edukacyjnych. Może w tym pomagać doświadczenie we własnej, dojrzałej twórczości artystycznej. Wszyscy wymieniani wcześniej towarzysze wolności są mi dobrze znani. Miewam lęki związane z procesem twórczym, wpisane w ciągłą ewaluację tego, co powstaje. Mam poczucie odpowiedzialności, niekiedy dotkliwe, za wytwór, proces, idee, odbiór i przekroczenia. Doświadczam, zapraszanej do uczestnictwa w twórczym procesie, dyscypliny dawkowanej przez odpowiedzialność. Dlatego patrząc przez pryzmat własnych artystycznych doświadczeń, lepiej rozumiem proces twórczy uczniów i widzę szereg podobieństw w pracy artysty i twórczej pracy dziecka. Zauważam również dodatkowy i ciekawy aspekt tej koincydencji, wpisujący się pięknie w przestrzeń wolności - zmaganie się ciekawości i znużenia. To zmaganie koreluje z wyborem: kontynuować pracę czy przestać. W pracy pedagogicznej chodzi o to, aby dziecko chciało i potrafiło uczestniczyć w inicjowanym procesie twórczym, zatem kluczowe jest szukanie sposobów, aby znużenie nie zdominowało ciekawości.

Chcąc zilustrować sugerowane zagrożenie, wynikające $\mathrm{z}$ twórczego zmagania, odwołam się do realizacji na bazie grafiki warsztatowej. W czasie pracy nad grafiką rodzenie się pomysłu bywa bolesne, ale poza kategorią 
dyscypliny intelektualnej i koncentracji, stanowi bardzo przyjemne i dość swobodne kojarzenie oraz przeszukiwanie zasobów pamięciowych. Etapem pracy najsilniej narażonym na znużenie jest samo wytwarzanie. To ta sfera działania związana ze stopniem technologicznej trudności, precyzją, możliwościami manualnymi, może nas satysfakcjonować lub zniechęcać. Jak zatem dobrać technikę do możliwości ucznia, uwzględniając wiek, wiedzę zastaną i osobnicze wyposażenie, aby utrzymać jego ciekawość i koncentrację? Przytoczę dwa przykłady działań.

Pierwszy dotyczy grupy dzieci z klas 0-3 szkoły podstawowej, które dostały zadanie zrealizować grafikę (il. 6). Zdecydowałam się na technikę monotypii m.in. dlatego, że jest techniką, którą można stosować po słownej instrukcji z krótką demonstracją. Nie wymaga ona równie żadnych niebezpiecznych narzędzi typu dłuta czy rylce. Wcześniej oczywiście konieczne było przygotowanie pracowni do planowanej brudnej pracy graficznej. $\mathrm{Na}$ dzieci czekały szyby z nałożoną czarną farbą drukarską, papiery do odbitek przygotowane w dostępnym i oczywistym miejscu, aby uczeń nie był skrępowany nieudaną próbą, mógł sam wziąć kartkę i zrobić kolejną od-

Il. 6. Monotypia wielobarwna, kl. I-III SP

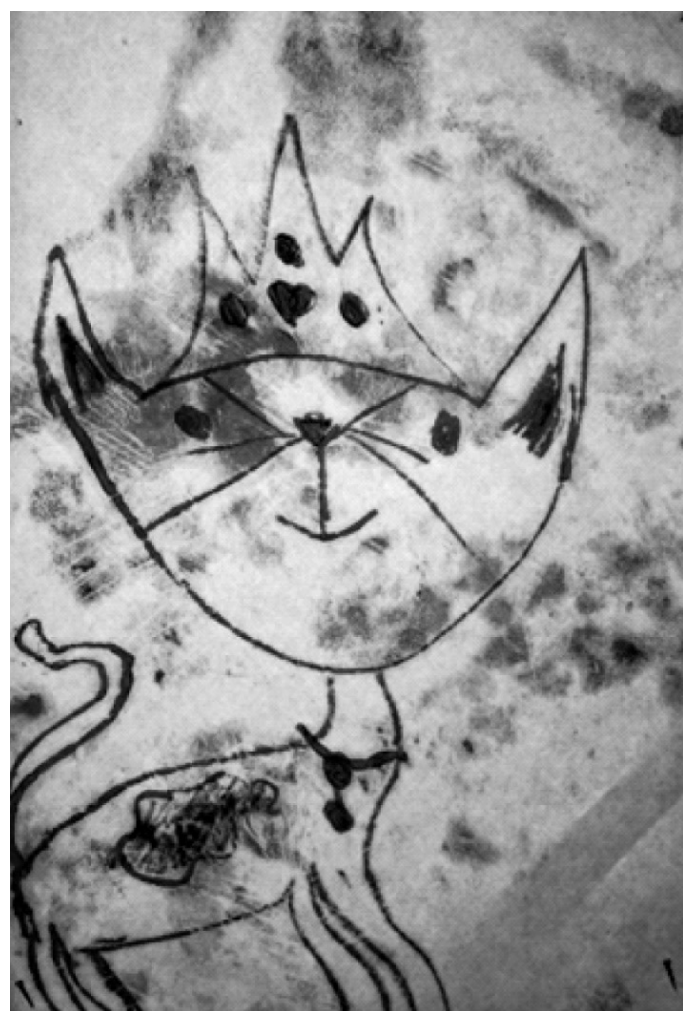


bitkę. Dzieci bez obaw przystąpiły do pracy, która powstawała na sugerowany przeze mnie temat, związany z pejzażem. Bardzo szybko powstało wiele odbitek. Mniej więcej po zrealizowaniu trzeciej dzieci, otrzymawszy słowne przyzwolenie na eksperymenty, zaczęły uwalniać proces twórczy od wstępnych ograniczeń. Zaproponowały temat dowolny. Poprosiły, aby im przygotować szyby z innymi kolorami i papiery większe niż A4. Zaczęły powstawać grafiki na wszystkim, co dzieci znalazły w pracowni, a co oczywiście w jakikolwiek sposób nadawało się do tego, na serwetkach, tkaninach, papierze toaletowym, kalce technicznej. Wielokrotne odbijanie prac nie powodowało znużenia. Oczywiście gdybym zatrzymała naturalnie rozwijający się proces twórczy na poziomie jednotematycznej i czarno-białej monotypii, w pewnym momencie wyczerpałaby się ciekawość uczniów. Również gdybym zaproponowała technikę bardziej złożoną, która wymaga planowania i precyzji, mogłoby to nie dać satysfakcji małemu dziecku.

Praca graficzna z młodzieżą wymagała innej propozycji. Technika druku wypukłego realizowana $z$ użyciem dłut graficznych i linoleum sytuuje zadanie na zupełnie innym poziomie odpowiedzialności i samodyscypliny niż wcześniej omawiana praca z monotypią. Tak jak w dojrzałej twórczości zaczyna się od pomysłu, który musi przyjąć formę materialną szkicu lub rysunku. Potem za pomocą kalki zostaje on przeniesiony na linoleum i wydłubywany specjalnym dłutem. Preparacja matrycy linorytniczej była dla młodzieży procesem żmudnym i mechanicznym, w czasie którego część osób skarżyła się na fizyczne i psychiczne zmęczenie (il. 7). Tylko ta część

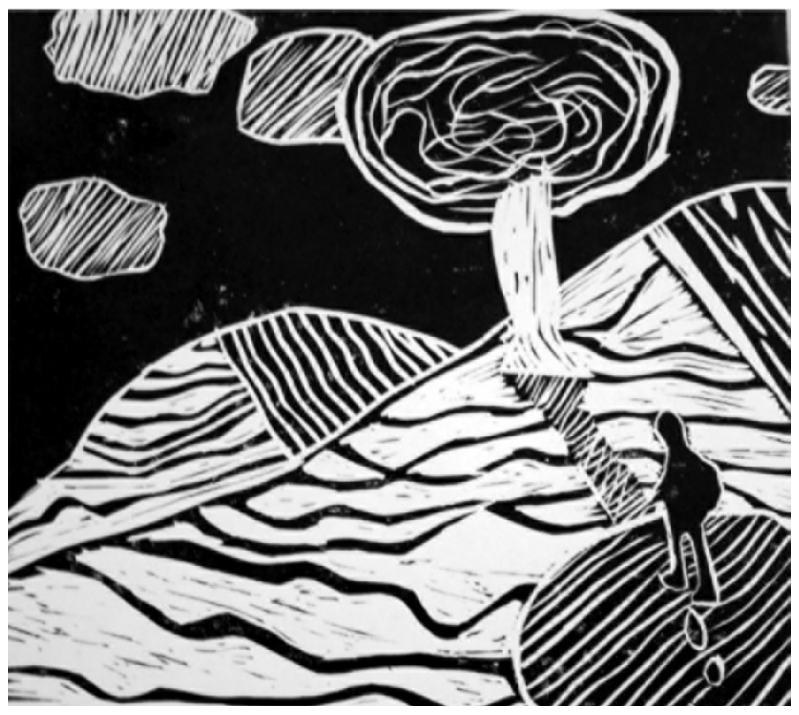

Il. 7. Linoryt, kl. I-III gimnazjum 
grupy z satysfakcją i pasją doprowadziła realizację do końca, która miała stosowną dawkę ciekawości wobec tego, co powstaje, i pełną akceptację własnego wstępnego projektu. Sytuacja emocjonalna uległa pewnemu wyrównaniu po pierwszych udanych odbitkach. Wzmocniły one wolę pracy nawet u najbardziej zniechęconych i pozwalały wykrzesać energię, aby powtórzyć czynność odbijania. Wiedząc, że proces wytwarzania grafiki może działać na młodzież zniechęcająco, warto oczywiście regulować poziom trudności, proponując chociażby małe formaty matrycy. Zapoznanie uczniów z trudną i technologicznie złożoną pracą grafika wzbogaca ich wiedzę o tym, czym jest twórczość. Młodzież zaczyna rozumieć, że tworzenie ma w sobie element zabawy i jednocześnie ciężkiej pracy.

Podsumowując, zaryzykuję twierdzenie, że rola pedagoga sztuki w świecie preferującym wolność i deprecjonującym wartości obiektywne powinna również koncentrować się na wolności. Wolności, która może być czynnikiem stymulującym efektywność działań nakierowanych na określony cel oraz specyficznie rozumianą "metodą” w działalności na polu edukacji. Możemy, projektując działania uczniów, oprócz myślenia o temacie czy technice, zastanawiać się, jaką proponować przestrzeń wolności, aby efektywnie i lepiej zrealizować cel: ile wolności, a ile konieczności pozwoli na optymalny twórczy proces wychowanka, tak aby nie bał się rozpocząć i nie znudził w trakcie realizacji.

\section{Bibliografia}

Alex B., Søren Kierkegaard - życie prawdziwe, Warszawa 1998.

Miksza M., Zrozumieć Montessori, Kraków 2009.

Nęcka E., Psychologia twórczości, Gdańsk 2002.

Pismo Święte Starego i Nowego Testamentu, Brytyjskie i Zagraniczne Towarzystwo Biblijne, Warszawa 1967.

Skorupka S., Auderska H., Łempicka Z. (red.), Mały słownik języka polskiego, Warszawa 1969. 